\title{
イスラーム政体における「統治の正当性」の 問題に関する現代イラン的展開
}

\section{A Contemporary Iranian Perspective on the Issue of the Legitimacy of Rule}

\author{
松 永 泰 行 \\ MATSUNAGA Yasuyuki
}

ABSTRACT Within the various theoretical perspectives of Islam, the issue of legitimacy of rule has traditionally been dealt with most notably as that of legitimate ruler. This apparently holds true in the both cases of the theory of the Sunni caliphate, and that of the Shi'ite infallible Imamate. The contemporary debate in the Islamic Republic of Iran over the differing perspectives on the sources of legitimacy of the rule of the jurist (wilāyat-i $f a q \bar{\imath} h$ ), on which I have previously published an article in this journal, was no exception.

In this article, I will further consider the question of legitimacy in Islamic rule by examining the contemporary debate in the Islamic Republic of Iran with the following steps. First, I will start the examination with bearing the following question in mind, that is, is it still convincingly arguable that the issue of legitimacy of rule in an Islamic regime can be adequately dealt with by considering who is the legitimate ruler, even after the establishment of an regime called "Islamic republic" in Iran? Second, I will attempt to enlarge the scope of the investigation by examining two articles written by Sa'īd Hajjāriān (b. 1954), a leading non-clerical theoretician of Iran today.

After carefully reading the two articles published in Rahbord and 'Așr-e $M \bar{a}$, respectively, I will preliminarily conclude that with the establishment of the Islamic Republic, a new perspective on the issue of legitimacy of rule in Islam, that is, the issue of the legitimacy of the regime has been successfully brought into the debate, and that very interestingly, this normative concept concerning the nature of the regime takes a logical precedence over the legitimacy of the ruler in the argument of Sa'îd Hajjāriān. The

* 日本大学国際関係学部専任講師

Assistant Professor, College of International Relations, Nihon University 
article ends with a note that in a future examination, I intend to further critically examine the so-called intikhābi perspective of the legitimacy of the wilayat-i faqih system in light of the expanded debate on the issue.

\section{序}

筆者は前考において，シーア派イスラーム神学 (Ilāhīyāt) の一部としての信 徒共同体のイマーム論 (Imāmah) と，シーア派イスラーム法学（fiqh）の一部 としての正当的統治権力論（salțanat-i mashrūah）とは，異なる展開力学を呈 するものであるとの仮説を示唆した。また別考において，イマーム幽隐の時代 における，「イスラーム法学者の統治」(wilāyat al-faqīh) の正当性 （mashrū'īyah）の根拠をめぐる，アーヤトッラー・ホメイニー師（Rūhollāh Mūsavī-Khomeinī, 1902-1989) 以来のシーア派イスラーム法学者間の論争を分 析した。これらを踏まえて，本論考においては考察の対象をさらに広げ，イス ラーム法学者以外の現代イランの政治理論家の議論を視野に入れ，シーア派イ スラームの文化的パラダイムが支配的な「国民国家」であるイラン・イスラー ム共和国における，「イスラーム政体における「統治の正当性」」の問題の議論 を, 総合的かつ批判的に考察するための一過程として，サイード・ハッジャー リアーン (Sa‘īd Hajjāriān, b. 1954) のイラン・イスラーム共和国における統治 の正当性の問題についての議論を批判的に検証する。

\section{I. イラン・イスラーム共和国における「統治の正当性」の問題への視座}

政治権力の制度的基礎とその行使の妥当性への問い，すなわち「正当性」 (legitimacy) の問題は，政治生活における最も古典的な問いであるといわれ る。個々の信仰者の救済への道筋の明示に並んで，信仰者の集まりとしての共 同体の正しいあり方に関する規定を強調するイスラームにおいても，統治の正 当性 (mashrūīyah) の問題は, 共同体の現実のあり方と密接に関わることにな るため，論理的にも，歴史的にも，極めて重要な役割を果たしてきたといえる。

イスラームにおいては，伝統的に，統治の「正当性」は，統治者の「正統性」

（いわば，出自および就任手続きの正しさ）に他ならない，という考えが支配 的であった。イスラームでは，いかなる権威の正当性もその根拠を究極的には 神（Allāh）に起因させることになるため，地上において樹立されるイスラーム 
政体（国家）に関しても，神のみに正統的に帰属する絶対的支配権（主権， hākimiyah）を，誰がどのような経路を経て委任されているかという問題と同 じものであると捉えられてきた。この意味では，伝統的なスンナ派イスラーム (法学)における「カリフ論」も，シーア派（神学）におけるイマーム論も， 同じ問題構成を基礎として（あるいは，「正統的統治者」のパラダイムとでも呼 べるものの枠内で）発展してきたといえる。もっとも，両者は，シーア派のイ マーム論が, 非正当性と表裏の関係にある, 妥当性への問いとしての「正当性」 (すなわち,「批判原理」としてのそれ)の意味合いをもって始まったのに対し， いわばエスタブリシュメント側の論理の追認として発展したスンナ派の伝統的 カリフ論が，秩序の維持を重視するという規範性は保ちながらも，批判原理と しての役割を帯びることがなかったのは対照的であった。

さて，こうして見てみると，1979年に成立したイラン・イスラーム共和国体 制（niẓām-i jumhūrī-yi Islāmī-yi Īrān）において，一名のシーア派イスラーム 法学者に，国家元首（統治者）ならびに社会（共同体）の指導の任務が課され ているのも，正統的統治者である「無謬のイマーム」が幽鿵中である状況下に おいて，「イスラーム法学者の統治」（wilāyat al-faqiih）論に基づき，条件を備 えたイスラーム法学者が,「正統性」を備えた統治者として権限を行使すること に，その統治システム（体制）の合法性および「正当性」があると，一見みな されうる(あるいは議論しうる) からであるといえる。

しかしながら，現存のイスラーム国家としてのイラン・イスラーム共和国の 執行権力の構築にあたっては，旧体制下における国家および社会運営に対する 国民各層の不満・反対を吸収した，実力行使に基づく蜂起としての反王運動の 事実が大きく寄与したことは否みがたい事実である。従って，いわば上部構造 的な部分はともかく，実力の行使という「世俗的」な論理に基づき，幅広い国 民多数が参加した「革命」の結果として成立したイラン・イスラーム共和国体 制においては，統治の正当性は，統治者の正統性につきるものではないとの問 題構成がなされてきても，不思議ではない。したがって，同国成立以後の「イ スラーム法学者の統治」論の展開において, 神任民選（intikhābī）説という, 統 治権の委讓と統治者の選定を区分する議論が出てきているのも，そのような事 実関係が背景にあるからであると理解できる。

以上の議論を踏まえて，本論考では，以下において，現代イランにおいてア 
ブドルキャリーム・ソルーシュ（'Abdolkarīm Sorūsh, b. 1945）と並ぶ，革命後 世代の非聖職者イスラーム主義者の代表的知識人である，サイード・ ハッジャーリアーンの「正当性」論を考察する。

\section{II. サイード・ハッジャーリアーンの「正当性」の問題についての議論}

ハッジャーリアーンは，これまで「統治の正当性」の問題に関して，革命後 イランの政治プロセスの性格に「質的変化」を加え，以後の同問題の議論にも 影響を与えることになる1997年の大統領選挙（いわゆる「ホルダード月 2 日選 挙」）以前の時期に，2つの重要な論考を発表している。本節では，それらにお ける議論の内容を順に整理してみる。
A. 1994年『ラーフボルド』誌論考

「正当性の問題の考察」と題され，イラン・イスラーム共和国における正当 性の問題について考えるための序論と宣言された本論考では，まず前置きとし て, 次の議論がなされる。西洋語の legitimacy に相当する最も適切なペルシャ 語の用語は, haqqānīyat ではなく, mashrūîyat である。その理由としては, 一方で，西洋（近代）語の legitimacy の概念は，法規範だけでなく，伝統，慣 習や革命などを根拠とする場合にも用いられること, また他方, mashrūīiyat と いう，委任の根拠（mașdar-i jalīi）を表す，（シーア派）イスラームの専門用語 が，立法者たる神が決定した事項に関わるものとして，既に存在しているから である。両者は, 前者が慣習を根拠とし，後者が神的な基盤を持つ点では対照 的であるように見えるが，実際には重なる部分が出てくる。例えば，イスラー ムで mashrū' (正当的) とされているものには, 神から明示的な禁止がされてい ないものや，イスラーム以前のアラブの慣習を神が認可しているものも含まれ ること，またイマームの幽鿵の時代においては，信仰者たる国民（jumhūr-i muslimin）が統治者の任命や罷免を決定するという原則は，信仰者のウンマが それ（すなわちその全体）として，神の意志に反する決定をすることができな いという理由で, mashrūiiyat を持つものであると論ずることも可能である。さ らにまた，イラン・イスラーム共和国で実施に移されているように，イスラー ム法学者全体 (fuqahā') が, 幽鿵のイマームの不特定代理人（nawwāb-i ‘āmm) として，信仰者のあり様に対し wilāyat を持つ（mutawallī-yi umūr-i ‘ubbād) とされ, さらにイスラーム法学者達がその合意 (ijmā’) や多数意見に 
よって，その中の一人に幽鿵のイマームの wilāyat と amānat を信託するとい う場合に，誰が walī-yi faqīh を選定するための専門性（khubriwiyat）を備え ているかは，法学者自身で決定（ta'yīn）される事項であるが，国民も複数の専 門家を選挙を通じて選出する（ことによってプロセスに参与する）枠組みにお いては，この仕組み (自体) が体制 (nizām) の mashrūīyat の根拠となってい ることなどが挙げられる。

次に，正当性 (mashrū'īyat) と正当化 (mashrū'īyatyābī) は明確に区別され るべきである。前者は統治の特徵を説明するある定まった状態を表すのに対し， 後者は統治において, その社会的基盤が拡大し，国民の満足度を增加させるプ ロセスをさしている。(両者は同じ正当性という概念を用いているが)前者では, それは規範的概念であるのに対し, 後者では社会学的（つまり経験的）な概念 である。すなわち，前者では，ある統治は正当性を持つか持たないかであるが， 後者においては，正当性は増減する量的概念である。

最後に, 統治の成立前の正当性と, 統治の成立後の正当性を混同しないこと が重要である。しかしこの場合に, 後者の正当性は統治の効率性（kārā'̄i wa kārāmadī）の一部であると主張されることもある。後者の議論が宗教的な側面 を持たされると，例えば，最良で最も効率的で，最も受け入れられている (maqbūl) 統治であっても，その正当性の根拠を宗教が定めた方法に置いてい なければ，正当性を持つものではない（nā-mashrū', ghāșib）といわれうるし， 逆に宗教的統治は，効率性や受容性を伴っていなくても，正当性を持つといわ れうる。

これらの前置きを踏まえ，次に，統治の正当性の根拠［起源］（manba“wa mansha'-i mashrū'īyat-i hukūmat-hā) は何にあるのかという問題の一般的考 察に進んでいる。そこではまず, 覇権（qahr, ghalabah）は正当性の根拠となり うるかという問いに対し，覇権はそれ自体では，第1の意味（すなわち規範と しての）の正当性を構成できないが, 統治を成立させた後で, 第 2 の意味の正 当性（すなわち効率性・受容性としてのそれ）を増すことはありうると論じて いる。本論の残りの部分は, ウェーバーの議論を一見, 想起させる内容となっ ており，第 1 の意味の正当性の根拠として，伝統 (sunnat)，カリスマ(farrih), 合理性 ('aqlāniyat) を挙げ, 議論をしている。本論考の観点から興味深いのは, 伝統に分類される正当性の根拠として，世襲（wirāthat），長老性（shaikhū- 
khīyat), 父長性 (ubūwat), 血縁・民族性（khūn, nizhād），エリート性 (nukhbah-girā’̄i) に加え，神的権利（haqq-i ilāhī）を挙げていることである。

本論考では，「正当性」概念について，何の正当性に関するものであるのかと いう点についても, 以下のとおり論じている。一般に, 統治者 (hukkām) や行 政官（șāḥib-i manșibān-i ijrā’̄i wa idārī）の正当性について語られることもあ る一方で，政治体制（rizhīm-i siyāsī）や社会体制（niẓām-i ijtimā‘̄i) の正当性 のあるなしが論じられることもある。問題がより明確になるように，以下に具 体例をもって考えてみる。

レザー・シャー期において，憲法によって彼の王権（salțanat）とその勅令が 正式に認められたが，ガージャール王朝の末裔は，この手続きを非正当的（nāmashrū゙) であると宣言した。(これは）彼らは，王制の原理（aṣl-i rizhìm-i salțanatī）や社会体制については，正当性を持つものと認めていたが，レザー・ ハーンの統治者性やかれの栜令は正当性を欠くものであるとみなしていた。

第三世界の多くの王国で，リベラル勢力は共和制を希求している。これらの 勢力は, (具体的な) 統治 (hukūmat) ならびに政治的主権（hākimīyat-i siyāsī) (の所在) が正当性を欠くとみなしている。しかし，社会関係（munāsibāt-i ijtimā'i)，例えば資本主義的関係（munāsibāt-i sarmāyahdārī) は正当的である とみなしている。従って，ブルジョア民主主義体制の確立のために力を注ぐ。

(各国の）共産党が「システム的な非正当性」（nā-mashrū'būdan-i sīstimī） について語るときに，彼らの言わんとするところは，統治者達（hukūmatgarān)，政治体制 (rizhīm-i siyāsī)，社会体制（niẓām-i ijtimā‘ī）やそこで覇権 的な諸関係（munāsibāt-i hākim bar-ān）のすべてが非正当的であるというこ とである。

(これらからわかるように）正当性の問題について論じる際（例えば体制の 正当性の基盤の拡大を進言する際）には，システムのどの側面について論じて いるのかを明確にする必要がある。また，もし社会体制と政治体制の正当性が ない場合に，統治者の正当性について語ることはできないように，これらの 3 種の正当性間の関係は確固たるものである。

B. 1995年『アスレ・マー』誌論考

「正当性，立憲制，共和制」と題された本論考では，まず，近代以降，一般 国民（tūdah-hā）の政治の舞台への登場と, 彼らによる政治参加の拡大要求で 
もって，正当性の伝統的な根趣が摇り動かされ，機能不全に陥る一方で, 近代 の諸条件から生み出された構造的変化が，正当性の新たな根拠を確立すること を要請している状況を,「正当性の危機」として捉えるとし, 以下の議論を展開 している。

「正当性の危機」において問題化しているのは，伝統型が前提としている， 統治者の統治権（haqq-i hukūmat kardan）が選挙や代表原理に基づいていな い点と，その権利が絶対 (無制限) 的 (muṭlaq) であるという点の 2 点である。 これらと近代政治の正当性の根拠である，代表制（wikālatī budan）と統治権 力の立憲制（mashrūt būdan-i iqtidār-i hukūmat bih shurūṭ-i qānūnī) が拮抗 している。この「正当性の危機」に対する歴史的な取り組みには,「立憲制の道」 （rāh-i mashrūtīyat）と「共和制の道」(rāh-i jumhūrìyat）があり，前者は英国 におけるマグナ・カルタ以来の立憲制確立への努力によって，後者はフランス 革命によって例示されている。イランにおいては，立憲革命において前者の道 における努力を行ったが，諸外国によるポス卜植民主義的介入を含む様々な構 造的要因の結果，その道は閉塞状態 (bin-bast) に陥った。立憲制のプロジェク トの崩壤を受けて, 社会勢力が峰起し, その問題を解決した。

（イラン）イスラーム革命は，伝統的正当性の諸形態から袂を分かつことに 基づいているため，イラン政治史において最も重要な出来事と位置付けられる べきである。この革命の指導部は, 革命成就の直後に，カリスマに基づく正当 性を合法化（qānūnī kardan）し，政治の近代的基盤を確立し，旧来の王制から 切り離すことに全ての努力を傾注した。従って，イスラーム革命後のイランは， 国民（tūdah-ha）の成熟により，その運命が彼ら自身の手中に収斿れ，信仰者 たる国民全体（jumhūr-i muslimīn）が，神意の担い手（hāmil-i mashìyat-i ilāhī）となっている，共和政期（'aṣr-i jumhūrīyat）と名づけられる。イスラー ム革命の最大の成果は,「イスラーム共和国」体制（nizāām-i jumhūrī-yi Islāmīi) の確立であり，その理由は，後者が，政治権力構造（sākhtār-i iqtidār-i siyāsīi) に変動をもたらし，国民の成長が要請するものに相応しい正当性の基盤（banāyi mashrū'iyat）を伴っているからである。イスラーム革命が示したとおり，イ ランにおける「正当性の危機」という結び目は，絶対権力を制限するという方 法ではほどけなかったが，これはその以前に，国民と国家の関係を（新たに） 確立することに到る, 国民主権（haqq-i hākimīyat-i milli)に基づく正当性の基 
礎が誕生する必要があったからである。「共和制の原則」(これがイスラーム革 命の中身 (maḍmūn) を構成するのであるが)の受容は, イラン国民が, イスラー ム, イスラーム法学 (fiqh), イスラーム法学者のウィラーヤ (wilāyat-i faqīh), 幽良 (ghaibat) の哲学，宣誓 (bai'at)，国民の利益 (mașlahat-i ‘āmmah)，憲 法やその他多くの概念に対する正しい理解（darak-i șahịhī）をその光で探し出 すことを可能とする。

（しかし）イスラーム革命以前の（政治権力）構造に繫がるものの一部の継 続(それらは宗教的な言説を使い政治の舞台で再び生産されてきているのだが) は，最も危険なものであり，確立されて間もないわれわれの共和制を危機にさ らしている。様々な服装に身を固めている旧来の体制の遺物 (baqāyā-yi nizāmi kuhan）を識別し，暴露することが，各々の政治勢力の義務であり，イスラー 厶革命とその根本的な宝である「イスラーム共和国」を守ることになる。

以上を枠組的理解として，ハッジャーリアーンは，イランの現在（1990年代 前半）の条件下における正当性の問題を以下のように考察している。

イランにおける現下の統治権の正当性は, 複合的な正当性 (mashrūinyat-i murakkab) であり，そのそれぞれの部分がかなりの重み（wazn）を持ってい るものである。これはまた，(現在のイラン）社会および政治勢力の成り立ちが, 複合的 (chand-sākhtārī wa murakkab) であることを説明している。西洋諸国 において，(現在）伝統的な正当化の形態が用いられることはまれであろうが, 第三世界においては，正当性の基盤が複合的であることは典型的（sirishtī）な ことである。今日イランでは, 社会の一部の層は, 伝統的理由（主長性 siyādat, 長老性 shaikhūkhīyat, マルジャア性, ムジュタヒド性, イマームの不特定代理 人性など）のゆえに，(ハーメネイー師の）指導者性（rahbarī）に服従（ița'at） している。また一部は, (故ホメイニ一師のカリスマの一部の移転, 個人の特徴, 革命の指導者の概念の継続などの理由で）彼にカリスマ的正当性を求めている。 また，一部は法的理由で (bih dalā’il-i qānūnī，憲法やその他の法的措置のゆえ に)，彼への忠誠が必要であると認識している。この複合的正当性は，イラン・ イスラーム共和国体制の現下の条件に特別なものではなく，故ホメイニー師存 命中にも，同様に 3 種より構成されていたものである。従ってなされるべきこ とは，ホメイニー師からハーメネイー師への移行期において，正当性の全体の 構成における，この伝統的，カリスマ的，合法的の 3 つの部分のそれぞれの重 
みと内容（maḍūn）が，どのような変更を経てきているかを考察することで ある。

イスラーム革命が頂点に達する前の時期におけるホメイニー師への忠誠は, 主に伝統的正当性の種類であったが，革命の成就がイラン国民の運命となって 以来，正当性のカリスマ的部分が強化され，(後者が）正当性の全体構成の中で 最も重みを持つ部分となるに到った。(1979年の) 憲法制定以後，合法的タイプ も前の 2 つに加わった。しかし，ホメイニー師は，(この新しい）体制の指導者 （rahbar）かつ創設者（mu'assis）であり,彼自身が憲法の創造者（khāliq）であ り，(その逆ではなく) 彼が憲法に正当性を与えたとさえいえるほどであったた め，同師の存命中においては，これらの 3 つの側面が（別個に）注目されるこ とはなかった。

同様に，これらの正当性の 3 つの側面が多くの人々の意識の中で融合してお り，区別することが不可能だったともいえる。つまり，彼らにとって，ホメイ ニー師への忠誠は，(同時に）マルジャエ・タクリード（イスラーム法学細則上 の権威）であり，革命の指導者であり，国家元首（ra'īs-i kishwar）でもあった 彼に対してのものであった。しかし問題を根底にまで突き詰めて見てみると，

（イランの）ある政治社会勢力は，ホメイニー師の命令と禁令（awāmir wa nawāhī) へ従うことの聖法的根拠（hujjat-i shar'īi) を，伝統的正当性の中に認 識しており，カリスマおよび合法性は，副次的あるいは付加・装飾的なものに 過ぎないと解釈していた。また別の勢力は，ホメイニー師をなによりもまず革 命の指導者で，イランの歴史に重要な貢献をした人物と認識しており，この側 面が彼らにとって同師の正当性の突出した部分であった。また第 3 の勢力に とっては，ホメイニー師の命令（awāmir）の正当性を，同師が国民の意見と監 督の代理人 (namāyandah-yi ārā wa nizāarat-i millat) であることの中に認識 していた。(しかし）いずれにしても，国民は同師の見解に従っており，その根 拠を精査する必要がなかったため，同師の崩御時まで，その正当性の問題が議 論されることはなかった。

ホメイニー師の崩御後，憲法改正において法的にも位置づけられた，宗教的 なマルジャア性（marja‘īyat-i dīnī）と政治的な指導者性（za‘āmat-i siyāsīi)の 分離は，伝統的およびカリスマ的合法性を，かなりの程度まで失わせることに なった。合法的正当性についても，(1990年の）第 2 期専門家会議（majlis-i 
khubrigān）選挙の過程を通じて批判されたように，この時期に一部政治勢 カより, 公然と無効であると宣言されるに到った。その結果, 全ての政治勢力 が, 政体とイスラーム革命の根本において, 何らかの補修 (chārah)を求め, 正 当性の根拠 (mabānī-yi mashrū'īyat) を強化することを求めた。(その) 理論的 また政治哲学的根拠が意識化され，各勢力がそれぞれの見解に基づき，この問 題の補修に乗り出したのも，同じ時期であった。（具体的には）ある勢力は，伝 統的な正当性の側面を強化する方向，すなわち， marja‘iyat と wilāyat を再び 整合させ, 融合させる方向へ目指し, 別の勢力は, 公には宣言されていない「革 命の中の革命」のテーゼでもって, カリスマの側面を強調し, さらに別のグルー プは，法的議論を通じて政体の共和制の側面と国民主権による正当性を強化す ることを希求するに到った。

正当性の伝統的側面を強化することを目指した勢力の政治哲学は以下のとお りであった。正当性の真の根拠は, (イスラーム法学者全体がもつ) 無謬のイマー ムの不特定代理人（nawwāb-i ‘āmm）としての wilāyat であり，（ハーメネ イー師は) 宗教的事項にウィラーヤ(監督権)を持つ正式な階級（qishr-i rasmīyi mutawalliyān-i umūr-i dīnī)の一員である。聖職者 (rūhānīyat) が手続きを 踏んで，その一員を選択し (bar-gazīd)，その者に権限（ikhtiyārāt）を与えた ときに，後者は「不特定代理人原理に基づく統治者」の地位 (simat-i wilāyati ‘āmmah) に就任するのである。その人物は, 聖職者から任命された（manșūb) 人物であるため, 彼の正当性はこの階級に由来するものであり, 前者は後者の 代表者 (namāyandah) であり, 後者に追随するものである。かれの罷免やコン トロールも, 従って, 聖職者階級の手中にある。このような統治 (hukūmat) は, 政治哲学的には, 聖職者という特権階級の貴族政体や神聖政体 (rabbānī-sālārī, ti'ukirāsī) とよばれるものであり，もし指導者が専門家会議を解散させるか， 専門家会議が指導者を罷免するかという選択を迫られた場合には，断固として 後者を選択する。同様に，この見解をとるグループは，聖職者階級と国民 （mardum）との間の代表・被代表の関係（rābițah-yi namāyan-digī) は存在し ていない (muntaqii) と認識しており，憲法（第107条）の解釈においても，国 民による専門家会議の選挙は，代表性の側面を含まないとしている。彼らによ ると, 正当性は, 社会の上層 (bālā) へと転移されてくる (muntaqil) ものであ るため, 下層（pā’̄in）には存在せず, 聖職者階層の正当性は, その本質において， 
無謬のイマームより与えられているものである。指導者性（rahbarī）は，この 階層の代表者であると自覚し，この階層の物質的および精神的利益を擁護する 限りにおいて，正当性を持つ。

これに対し，正当性のカリスマの側面を強化することを目指した第 2 のグ ループは, 政治哲学的には,「絶対的ウィラーヤ」（wilāyat-i muțlaqah）説の 立場をとり, 従って, 指導者に対して無謬のイマームより一種の特定代理権 (niyābat-i khāṣs) が与えられていると考えている。彼らによれば，統治権 （wilāyat）や正当性を指導者に授与することは誰にもできず，統治の根幹にと どまらない，(聖職者階層を含む) 全てのものが，その正当性を指導者から供与 されている。正当性は, 社会のピラミッドの頂点に存在しており, 上から下へ と流出するのである。このような統治は, 政治哲学的には, 専制 (utukirāsī) や 独裁制（yikkah-sālārī）と呼ばれる。このグループは, 上述の二者択一の問いに 対しては，専門家会議の正当性は，指導者（個人）から授けられるものであり， 彼の絶対的ウィラーヤは，憲法に対しても及ぶ（hākim）ため，指導者自身が， 自分の後継指導者を任命（ta'yin）するための手続きを（憲法の規定にかかわら ず）定めることができると考える。このグループは，聖職者階層と指導者（さ らに国民と指導者）の代表・被代表関係は存在していないとし，憲法 (第107条) 解釈においても, 専門家会議は, 指導者を任命 (nașb) するのではなく, (muqallid と muqallad の関係と同様に)「発見」(kashf) するだけであるとす る。従って, 聖職者も一般国民も指導者に対する正当性の付与には与らず，指 導者は, 神以外に対して（実定法的 huqūqī な意味での）説明責任をもつ (pāsukhgū) ことはない。このグループの見解によれば, 正当性は指導者(個人) の特質に存在しているものであり，この正当性の存続のためには，永続的に革 命の形態を維持し, 指導者のカリスマが減衰しないようにする必要がある。

正当性の合法的側面に根本的な価値を置く，第 3 のグループは，指導者は国 民主権の代表者（namāyandah-yi hākimīyat-i millī）であるとの政治哲学的立 場をとる。この立場によれば，指導者の意見（ra'y）は，国民の意見（ra'y-i millat）と同じである。憲法 (第57条) の絶対的監督権（wilāyat-i muṭlaqah） の解釈においても，国民主権が絶対であるため指導者も絶対であるとし，この 状態はイランに特殊なものではないとする。このグループは, 憲法により規定 されている指導者の選出のための段階的手続きのすべてが，代表の原則に則る 
ものである，すなわち体制の指導者（rahbar-i nizām）は，二段階の選挙を通じ て，国民から任命や罷免を受けるとみなしている。初代の指導者が，憲法の創 造者であったのに対し, (現) 指導者は, 憲法の産物 (makhlūq-i qānūn-i asāsī) であり，それゆえ，憲法を越えた立法行為を行うこと，特に共和制とイスラー ム性についての変更不能の原理に変更を加えることは許されない。このグルー プの見解によれば，信仰者たる国民全体の意見（ra'y-i jumhūr-i muslimīn）は 正当性を持ち，神意の手 (dast-i irādah-yi ilāhī) が国民のそで (āstīn-i millat) から出てくるのである。従って，国民が，指導者に対する信認（bai'at）でもっ て，この正当性を彼に転移させることになる。この方法は，神聖民主制（ti'udimukrāsī, khudā-mardumsālārī) と呼ばれる統治形態（hukūmatdār）の一解 釈である。このグループは，専門家会議の立候補者に関するいかなる制限 (tadyiq）にも反対であり，マルジャア性と指導者性の概念的区別以後，体制の 正当性（mashrū'îyat-i nizām）の社会的基盤の強化と拡大のために，専門家会 議のメンバーは必然的に，聖職者だけから選ばれるのではなく，その構成はイ

ラン社会全ての構成にできるだけ近いものであるべきであると考えている。

これらの区分は, 諸勢力の間に, 体制の正当性の根本的な起源（sārchashmah-yi asli-yi mashrū'īyat-i nizām) に関して, (共通の) 法的基盤が存在し ていないことを示すために行った。同じこと，すなわち，専制に始まり，貴族 制を経て民主制へと到る諸解棌の拡大が，イランにおける「正当性」をめぐる 隠れた難題を引き起こしているのである。現実には, 第 1 のグループの見解が 優勢である，第 2 の見解も生き残りに努力している。他方，社会的理由により， 第 1 の見解はかなりの後退を迫られている一方，第 3 の見解は理論面以外では， 日の目を見ていない。

これらの，体制の正当性の基盤（pāyah-yi mashrū'īyat-i nizām）に関する相 反する見解は, 憲法の中においても明らかになっている。これは, 憲法制定 (専 門家）会議（および憲法改正会議）のメンバーが，意図的に，明確にしないこ とにしたからでもある。その結果，憲法の条項の解釈において，相反する側面 の強調が可能になっているのである。

\section{III. 批判的検証}

前節で整理した内容から明白であるように, ハッジャーリアーンの「正当性」 
に関する議論は, イスラーム学以外の政治学, 社会学における議論をも踏まえ ており，概念的にも，論理的にも極めて明晰かつ分析的ものとなっている。ま た，第二共和制」とも呼ばれる，ホメイニー師没後のイラン・イスラーム共和 国の体制（nizām）および統治者（rahbar）の正当性の問題について，最大限に 大胆かつ具体的に議論を展開している点も, 注目に値する理由の一つである。 ハッジャーリアーンが議論している「正当性」は，規範概念（すなわち，い わば「質的問いかけ」）としてのそれである。「正当性の根拠（起源）」(manba“ wa mansha'-i mashrūīyat) の考察という問題設定自体が，このことを示して いる。従って, 彼の議論はこの点では, イスラーム法学者の間の,「イスラーム 法学者の統治」の正当性の根拠を巡る議論と，パラレル関係にある。またそれ は, 後者の議論と同様に, 規範概念ではなく, 量的な経験概念である, 統治の 受容性 (maqbūlīyat) や効率性 (kārāmadī) の問題の考察とは一線を画してい る。

ハッジャーリアーンの議論が，イスラーム法学者の間の議論を超えている点 は,「イラン・イスラーム共和国における正当性の問題」という問題設定をする ことによって,「統治者の正統性」の枠組みを超えて,「体制の正当性」 (mashrūīyat-i nizām) を別個に考察することを可能にしていることにある。も ちろん, イスラーム法学者の間の議論も, wilāyat al-faqin 体制の妥当性を議論 する部分を含んではいるが，その内容は実際には，条件を満たしたイスラーム 法学者が統治を行うことと同値されているため, 別個の議論としては成立して いない。それに対して，『アスレ・マー』誌論考の前段での，「正当性の危機」 という概念を持ち出してのハッジャーリアーンの議論は, 政治体制と（世俗的 な意味での）社会变動を連動させた，いわゆる政治発展論的なスキーマティッ クな議論の体裁を取っているが，「一般国民（tūdah-hā) の政治の舞台への登場 と, 彼らによる政治参加の拡大要求」と「イスラーム共和制」の確立を関連付 けている点が独自な点である。これにより,「共和制」原理, すなわち国民主権 原理を，「体制の正当性」の根拠（起源）の連鎖の一部に組み込むことを必然と し，後者の規範的基盤を拡大することに成功している。

このことからも容易に推論できるとおり，ハッジャーリアーンは，統治シス テムとしての「体制」（nizām）の正当性が，統治者個人の正当性に「規範的優 先性」をもっていると考えていると判断される。すなわちイラン・イスラーム 
共和国の文脈でいえば，「イスラーム共和制」という体制の正当性が，その体制 における「正当な」統治者である「指導者」(rahbar) の正当性を上回る重要性 を持っているとの立場をとっているのである。もっとも，これは論理上の順序 であり，現実の時系列的には，『アスレ・マー』誌論考において論じてあるとお り，革命の指導者（統治者）が，イラン・イスラーム共和国憲法に先行するの ではあるが，国民投票によりイスラーム共和国体制が採択され，一旦憲法が成 立した後では,「体制の正当性」は, 革命の指導者個人の「正当性」から, 論理 的独立性ならびに規範的優越性を獲得していると考えていると判断できる。

ハッジャーリアーンの「体制の正当性」と「統治者の正統性（正当性）」の論 理的峻別は，さらに，批判原理としての「正当性」概念の強化にもつながって いる。このことは，前者と後者の整合性を質的に問うことにより成立している。 具体的には，憲法に規定された手続き的には「正当」である，「指導者」の現状 の選出方法を，国民主権の行使が実現している間接選挙であると仮に解釈する としても, 専門家会議のメンバーが聖職者に限定されている制度的現状を,「共 和制原理」(国民主権）との非整合性を基に，「批判」していいる点である。 ハッジャーリアーンが展開している正当性の根拠の三類型に基づくイラン・ イスラーム共和国内の正当性議論の立場の分析は, 単にその内容が現実の党派 (思想傾向) の区分に関して有益 (informative) であるだけでなく，「正当性」 概念の内容についての考察としても価值が高いものである。彼の三類型（伝統， カリスマ, 合法性) は, ウェーバーの三類型と一見, 同じであるが, 以上の検 証からも明らかなとおり，後者が支配が安定的に受容される基盤を社会学的に 考察するための類型であるのに対し，ハッジャーリアーンのものは規範概念， すなわち支配の妥当性を質的に問うための規範（基準）としての正当性の内容 の類型であるため，根本的に異なるものである。これにより，イスラーム法学 者の間の,「法学者の統治」の正当性の根拠をめぐる議論についても，その「正 当性」の内容，すなわち，「手続き的に妥当であること」以上の中身についても， 考えることを可能としている。具体的には，同じ「神任」（intișābī) 説でも，

「不特定代理人」(wilāyat-i ‘āmm) 説が, 聖職者階級の利益の代弁を正当性の 内容としているのに対し，「特定代理人」(wilāyat-i khāșs）説の正当性の内容 は，いわば超人的なカリスマであることが説明されている。 


\section{結 語}

本論考では，「統治の正当性」は「統治者の正統性」につきるのか否かを問題 意識としながら，イラン・イスラーム共和国の文脈にそってこの問題を考える 一過程として，サイード・ハッジャーリアーンの議論を検証した。検証の内容 からも明らかなとおり，規範概念，あるいは，政治システムのあり方に対する 質的問いかけとしての「正当性」の議論は，同国下において，「統治者の正統性」 の枠組みを超えた，「体制の正当性」を優越規範とする議論に発展してきている ことが，見て取れた。

ハッジャーリアーンの議論においては，イラン国内のこの問題をめぐる立場 が 3 つに収斂させられていたが，この議論に基づくと，イスラーム法学者自身 の間の「イスラーム法学者の統治」論の民主主義派（あるいは良識派）ともい える，神任民選（intikhābī）説が，いかに根拠が希薄で，政治理論的に中途半端 な立場を主張しているかということが浮き彫りにされたことも，付随的な成果 といえるであろう。

注

本稿は, 公益信託斎藤稜兒イスラム研究助成基金平成 12 年度助成研究「イスラーム 政体における正当性の問題」の成果の一部である。

(1) Yasuyuki Matsunaga, "Examining the Views of 'Allamah Majlisi on Legitimate Political Authority (sultanat-i mashrîu'ah) and the Guardianship of the Jurist (wilâyat-i faqîh), " Orient XXXV (2000), 12-21.

（2）松永泰行「ホメイニー師以後のヴェラーヤテ・ファギーフ論の発展とそれを巡る 論争」『オリエント』42/2 (1999)，61-79。但し同稿においては，正当性 (mashrūīyat) の内容については，考察を省略していた。

（3）佐々木毅『政治学講義』東京大学出版会，1999，90。佐々木の議論は，ウェーバー 以来，正当性といえば，権威（支配）の受け入れの根拠としての受動的（あるいは経 験主義的）な側面が強調されがちであるが，政治権力の制度的基礎とその行使の妥当 性への問いとしての正当性は，政治的服従の「限界」の発見や抵抗権の行使への根拠 ともなる能動的（あるいは規範的）な側面を持つものであり，特に後者の意味で，政 治に関する古典的な問いかけの一つであるとの意味である。

（4）鎌田繁「イスラームおける権威の構造」脇本平也，柳川啓一 (編)『権威の構造と 破壞』現代宗教学 4, 東京大学出版会, 1992，115。

（5）小杉泰はこれを，主権行使権の委託（代理執行）の問題として総括している。「現 代イスラム思想における主権と国家—スンニー派・シーア派の政治概念をめぐって」 
『日本中東学会年報』1（1986），1-23，および『現代中東とイスラーム政治』昭和堂, 1994，第 2 章, 参照。

（6） スンナ派 (法学) の伝統的カリフ論については, 中田考「イスラーム法学に於け るカリフ論の展開」『オリエント』33/2（1990)，79-95, を参照されたい。この文脈で 考えると, 中田のいう, イブン・タイミーヤによる伝統的カリフ論の「解体・再構築」 は，スンナ派法学のカリフ論に批判原理としての正当性を付与するものであったとい うことになる。従って, 批判勢力としての近現代のスンナ派イスラーム復興主義運動 がイブン・タイミーヤの流れを汲んでいることは，この文脈からも理解できる。対照 的に, シーア派の場合には，伝統的なイマーム論の流れを汲む「イスラーム法学者の 統治」論が，イラン・イスラーム革命運動の規範原理となり得たことの理由の一つに は，伝統的イマーム論自体に批判原理としての正当性への問いが含まれていたからで あったといえる。

（7）「イスラーム法学者の統治論」（wilāyat al-faqīh）における wilāyah 概念の意味 合いについては，拙稿「「ヴェラーヤテ・ファギーフ」（velayat-e faqih）とは何か?

『中東研究』455（1999年10月），16-22，を参照されたい。

（8）ハッジャーリアーンの略歴・思想傾向に関しては別稿 (“The Development of the Islamic Left's 'Democratic' Discourse in Post-Khomeini Iran,” forthcoming) で論じ たので, 本論考では割愛する。略歴については, Sahrām Rafī‘zādeh wa Nīmā Tamaddon, Shillīk bih Iṣlāhāt: Nigāhī bih Tirur-i Sa'īd-i Hajjāriānn (Tehran: Aknūn, 1379), 95-101; 'Emād al-Dīn Bāqī, Barāy-i Ta'rīkh: Guftugū bā Sa'īd Hajjāariān (Tehran: Nei, 1379), 16-56, が詳しい。

( 9 ) Sa‘ìd Hajjāriān, "Nigahi bih Mas'alah-yi Mashrū'īyat," Rāhbord 3 (Spring 1994), 78-93.

(10) Ibid., 79-81.

(11) Ibid., 82-85.

（12）Ibid., 83-84. 同論考のこの後の部分 (85-91頁) は, 正当化過程 (farāyand-i mashrū'iyatyābī), 服従 (ițā'at) の理由, 正当性の複合性, 正当性の危機についての一 般的な議論をしているが，次の『アスレ・マー』誌論考と重複しているので割愛する。

(13) Ibid., 91-92.

(14) “Mashrū'īyat, Mashrūṭīyat, Jumhūrīyat," 'Aṣr-e Mā 14 (May 1995), 4, 7; reprinted in Sa'īd Ḥajjāriān, Jumhūrīyat: Afsūn-zadā'̀ az Qudrat (Tehran: Tarḥ-e Nou, 2000)，46-55. 引用は後者に拠る。

(15) Jumhūrìyat, 46-50.

(16) Ibid., 51.

(17) Ibid., 51-52.

（18）イスラーム左派勢力を指す。専門家会議（majlis-i khubrigān-i rahbarī) は，イラ ン・イスラーム共和国憲法（1979年制定，1989年改正）により設置されている，80余 
名のイスラーム法学者よりなる機関であるが, 第107条において規定されている同会議 の役割および権限については, (ハッジャーリアーンも以下で指摘するとおり) 憲法制 定時より複数の解䣋が可能になる暧昧さが残されてきている。その背景の考察につい ては, 前掲拙稿（「ホメイニ一師以後のヴェラーヤテ・ファギーフ論の発展とそれを巡 る論争」)，68-75，を参照されたい。

(19) Jumhūrìyat, 53-54.

(20) Ibid., 54-55.

(21) Ibid., 55 .

(22) Hajjāriān, "Nigāhī," 82.

(23) Ibid., 78; Jumhūrìyat, 50-51.

(24) Max Weber, "The Types of Legitimate Domination," in Economy and Society, ed. Guenther Roth and Claus Wittich (Berkeley: University of California Press, 1978), vol. 1, 212-301.

（25）余談ながら，前者の議論（特殊階級的利益）は聖職者以外に対するアピール度が 低いため，公式ドクトリンとしては採用されにくいのに対し，後者（神による個人任 命による就任）はドクトリンとしては完全無敵に近いものの，実践面では手続き的に 各種の困難さを伴うように思われる。イラン・イスラーム共和国で今日，実践されて いるのは前者（例えば，実際の指導者の選出は複数候補間の多数決で決定される）に ほぼ近いが，公式ドクトリンとして喧伝されているのは後者である。

（26）従って, 後続の検証では, 同説の代表的な若手理論家である, モフセン・キャディー ヴァル師（Mohsen Kadīvar, b. 1959）の議論を検証してみたい。 